\title{
Efforts Estimation by Use Case Point using Experience Data
}

\author{
Chetan Nagar ${ }^{1}$, Anurag Dixit, PhD. ${ }^{2}$ \\ ${ }^{1}$ Ph.D Student, Mewar University (Gangrar) Chittodgarh Rajasthan India \\ ${ }^{2}$ Dean-Professor (CS/IT) BRCM CET,Bahal Bhiwani
}

\begin{abstract}
Many software efforts estimation models and methods are invented to make efforts estimation accurate. Unfortunately no model or method is suitable for all kind of project and situations. it is frequently suggested that using experience data, estimation models and checklists can increase software effort estimation accuracy. However, there has been limited empirical research on the subject. It was found that in projects where experience data was utilized in the estimation process, they experienced a lesser magnitude of effort overruns. The use of a checklist also appeared to increase estimation accuracy. The utilization of an estimation model did not appear to have a substantial impact [08].This paper is suggesting that use of estimation model can also produce good estimation results, but historical data is always necessary to assist the estimation. We can use historical data to improve the result of Use Case Point and COCOMO model .In our research we have gain $10 \%$ improvement in Use case Point model with use of historical data. This paper is also suggesting that a strong monitoring policy is always required to make your estimation as a success.
\end{abstract}

Keywords: Software estimation, experience data, estimation models, checklists, COCOMO, Use Case Point.

\section{INTRODUCTION}

We should accept that Estimation by Analogy and Expert Estimation are good estimation technique, it means not that estimation model cannot produce good result. Historical data provide a strong base to our prediction. It makes our prediction better. Use of historical data can also improve the performance of estimation model that we have shown in this paper.

Estimation is an important part of software engineering process, and the ability to produce accurate effort estimates has an impact on key economic processes, including budgeting and bid proposals. Projects estimated optimistically might be selected instead of a project that has been estimated pessimistically [2]. If organizations want to improve the accuracy of their employees "effort estimates, employees must be trained to make better estimates. It has already been established that estimation ability does not increase with experience [10].

In [4], Jørgensen raises the issue of why estimation models are not applied by project managers more frequently. He argues that the lack of evidence for their efficacy may be the most significant reason.

Most of the estimation done today is expert-based. Research has shown that the average effort overrun in software development projects is about $30 \%-40 \%$ [1].
Today we are referring old data only in Analogy Based Estimation and Expert Estimation. We can also use the historical data to improve the accuracy of an estimation model.

\section{METHODS OF EFFORTS ESTIMATION}

It is necessary understanding the principals of each estimation method to choose the best. Because performance of each estimation method depends on several parameters such as complexity of the project, duration of the project, expertise of the staff, development method and so on [14].

COCOMO and Use Case Point is two most popular models used for estimation. In the COCOMO we have to predict two things first is how much KLOC will required to build that project and second 22 Efforts Adjustment Factors .Historical data can guide us to predict how much KLOC will required to build the project and it can also help in the prediction of EAF. For the effective utilization it is necessary that database must be well managed. We must record the values of the parameters and reason why we had chooses that value .A database of previous successful project must be maintain for future reference.

Use Case Point is another popular in which we need to predict Actors, Use Case, TCF and EF.

\section{A. $\mathrm{COCOMO}[9]$}

One after one three models of COCOMO given by Barry Boehm:

$\begin{array}{ll}\text { i. } & \text { Simple COCOMO. } \\ \text { ii. } & \text { Intermediate COCOMO. } \\ \text { iii. } & \text { Advance COCOMO }\end{array}$

i.Simple COCOMO:- It was the first model suggested by Barry Boehm, which Follows following formula:

Efforts $=a^{*}(\text { KLOC })^{b}$

Here $\mathrm{a}$ and $\mathrm{b}$ are complexity factor.

TABLE I

Complexity Factors

\begin{tabular}{|l|c|c|}
\hline Model & $\mathrm{A}$ & $\mathrm{B}$ \\
\hline $\begin{array}{l}\text { Organic (simple in terms of size } \\
\text { and complexity }\end{array}$ & 3.2 & 1.05 \\
\hline $\begin{array}{l}\text { Semi-ditched ( average in terms of } \\
\text { size and complexity }\end{array}$ & 3.0 & 1.12 \\
\hline Embedded ( Complex) & 2.8 & 1.20 \\
\hline
\end{tabular}


ii Intermediate COCOMO:-Previous model does not include the factors which can affect the efforts. Intermediate COCOMO includes 17 factors that can affect the efforts estimation.

Efforts $=a^{*}(\text { KLOC })^{b} * E A F$

Here $\mathrm{a}$ and $\mathrm{b}$ are complexity factor.

TABLE II

Complexity Factors

\begin{tabular}{|l|c|c|}
\hline Model & A & B \\
\hline $\begin{array}{l}\text { Organic (simple in terms of size } \\
\text { and complexity }\end{array}$ & 3.2 & 1.05 \\
\hline $\begin{array}{l}\text { Semi-ditched ( average in terms of } \\
\text { size and complexity }\end{array}$ & 3.0 & 1.12 \\
\hline Embedded ( Complex) & 2.8 & 1.20 \\
\hline
\end{tabular}

Following are Efforts Adjustment Factors used in Intermediate COCOMO. Typical values for EAF range from 0.9 to 1.4 .

TABLE III

Cost Drivers

\begin{tabular}{|c|c|c|c|}
\hline $\begin{array}{r}\mathbf{S} \\
\mathbf{N} \\
\mathbf{O}\end{array}$ & $\begin{array}{l}\text { Cost } \\
\text { Driver }\end{array}$ & Value & Description \\
\hline 1 & DATA & & Database size. \\
\hline 2 & CPLX & & Product complexity. \\
\hline 3 & TIME & & $\begin{array}{l}\text { Execution } \\
\text { constraint. }\end{array}$ \\
\hline 4 & STOR & & Main storage constraint. \\
\hline 5 & RUSE & & Required reusability. \\
\hline 6 & DOCU & & $\begin{array}{l}\text { Documentation match to } \\
\text { life-cycle needs. }\end{array}$ \\
\hline 7 & PVOL & & Platform volatility. \\
\hline 8 & SCED & & Scheduling factor. \\
\hline 9 & RELY & & Required reliability. \\
\hline 10 & TOOL & & Use of software tools. \\
\hline 11 & APEX & & Application experience. \\
\hline 12 & ACAP & & Analyst capability. \\
\hline 13 & PCAP & & Programmer capability. \\
\hline 14 & PLEX & & Platform experience. \\
\hline 15 & LTEX & & $\begin{array}{l}\text { Language and tools } \\
\text { experience. }\end{array}$ \\
\hline 16 & PCON & & Personnel continuity. \\
\hline 17 & SITE & & Multisite development. \\
\hline
\end{tabular}

Scale factors are new in COCOMO II. The effect of scale factor is in 1.01 to 1.26 ranges

TABLE IV

New Cost Drivers

\begin{tabular}{|l|l|l|l|}
\hline S NO & $\begin{array}{c}\text { Cost } \\
\text { Drive } \\
\mathbf{r}\end{array}$ & Value & Description \\
\hline 18 & PREC & & Precedence. \\
\hline 19 & PMAT & & Process maturity. \\
\hline 20 & TEAM & & Team cohesion. \\
\hline 21 & FLEX & & $\begin{array}{c}\text { Development } \\
\text { flexibility. }\end{array}$ \\
\hline 22 & RESL & & $\begin{array}{c}\text { Architecture and risk } \\
\text { resolution. }\end{array}$ \\
\hline
\end{tabular}

What we have to predict in the COCOMO, first we have to predict KLOC, second parameters specified in Table-III and Third Parameters specified in Table-IV. Experience data can help us in prediction. Now suppose we have a rich database for such kind of project so which projects can be taken as reference, Answer is that we must keep two parameters in mind first we have to take latest project and second we have to take successful project.

\section{B. Use Case Point [3] [13].}

The Use Case Points (UCP) method provides the ability to estimate the man hours a software project requires from its use cases. Based on work by Gustav Karner [1], the UCP method analyzes the use case actors, scenarios, and various technical and environmental factors and abstracts them into an equation.

The UCP equation is composed of three variables:

1. Unadjusted Use Case Points (UUCP).

2. The Technical Complexity Factor (TCF).

3. The Environment Complexity Factor (ECF).

A. Calculate no of Actors:-We use following table to calculate no of Actors used in project

TABLE V

Actor Calculation

\begin{tabular}{|l|l|l|c|c|}
\hline $\begin{array}{c}\text { Actor } \\
\text { Type } \\
\mathrm{n}\end{array}$ & $\begin{array}{l}\text { Descriptio } \\
\text { Simple }\end{array}$ & $\begin{array}{l}\text { Quantit } \\
\mathrm{y} \\
\text { API }\end{array}$ & $\begin{array}{l}\text { Weigh } \\
\mathrm{t} \\
\text { Factor }\end{array}$ & $\begin{array}{l}\text { Subtota } \\
\mathrm{l}\end{array}$ \\
\hline Average & $\begin{array}{l}\text { Interactive } \\
\text { or protocol } \\
\text { driven } \\
\text { interface }\end{array}$ & 1 & 2 & \\
\hline $\begin{array}{l}\text { Comple } \\
\mathrm{x}\end{array}$ & $\begin{array}{l}\text { Graphical } \\
\text { user } \\
\text { interface }\end{array}$ & & 3 & \\
\hline \multicolumn{2}{|l|}{ Total Actor Points } & & \\
\hline
\end{tabular}

B. Calculate no of Use Cases:-We use following table to calculate no of Use Cases used in project

TABLE VI

Use Case Calculation

\begin{tabular}{|l|l|l|l|l|}
\hline $\begin{array}{l}\text { Use } \\
\text { Case } \\
\text { Type }\end{array}$ & Description & $\begin{array}{l}\text { Quant } \\
\text { ity }\end{array}$ & $\begin{array}{l}\text { Weight } \\
\text { Factor }\end{array}$ & Subtotal \\
\hline Simple & $\begin{array}{l}\text { Up to 3 } \\
\text { transactions }\end{array}$ & 5 & \\
\hline Average & $\begin{array}{l}4 \text { to 7 } \\
\text { transactions }\end{array}$ & 10 & \\
\hline Complex & $\begin{array}{l}\text { More than 7 } \\
\text { transactions }\end{array}$ & 15 & \\
\hline \multicolumn{2}{|l|}{ Total Use Cases } & & \\
\hline
\end{tabular}

UUCP $=$ Weighted Actors + Weighted Use Cases

$\mathrm{UCP}=\mathrm{UUCP} * \mathrm{TCF} * \mathrm{EF}$

Calculate TCF (Technical Complexity Factor)

List of Technical factors where weight factor rate from 0-2 and project rating rate from $0-5$ 
TABLE VII

Technical Complexity Factors

\begin{tabular}{|c|c|c|c|c|}
\hline \multicolumn{5}{|c|}{ Technical Complexity Factors } \\
\hline $\begin{array}{l}\text { Technic } \\
\text { al } \\
\text { Factor }\end{array}$ & $\begin{array}{l}\text { Factor } \\
\text { Description }\end{array}$ & $\begin{array}{l}\text { Wight } \\
\text { Factor }\end{array}$ & $\begin{array}{l}\text { Project } \\
\text { Rating }\end{array}$ & $\begin{array}{l}\text { Sub } \\
\text { Total }\end{array}$ \\
\hline $\mathrm{T} 1$ & $\begin{array}{l}\text { Must have a } \\
\text { distributed } \\
\text { solution }\end{array}$ & 2 & & \\
\hline $\mathrm{T} 2$ & $\begin{array}{l}\text { Must Respond } \\
\text { to specific } \\
\text { performance } \\
\text { objective }\end{array}$ & 1 & & \\
\hline T3 & $\begin{array}{l}\text { Must meet end } \\
\text { user efficiency } \\
\text { desired }\end{array}$ & 1 & & \\
\hline $\mathrm{T} 4$ & $\begin{array}{l}\text { Complex } \\
\text { internal } \\
\text { processing }\end{array}$ & 1 & & \\
\hline T5 & $\begin{array}{l}\text { Code must } \\
\text { reusable }\end{array}$ & 1 & & \\
\hline T6 & $\begin{array}{l}\text { Must be easy } \\
\text { to install }\end{array}$ & 0.5 & & \\
\hline $\mathrm{T} 7$ & $\begin{array}{l}\text { Must be easy } \\
\text { to use }\end{array}$ & 0.5 & & \\
\hline T8 & $\begin{array}{ll}\text { Must } & \text { be } \\
\text { portable } & \end{array}$ & 2 & & \\
\hline T9 & $\begin{array}{l}\text { Must be easy } \\
\text { to change }\end{array}$ & 1 & & \\
\hline T10 & $\begin{array}{l}\text { Include special } \\
\text { security } \\
\text { feature }\end{array}$ & 1 & & \\
\hline T11 & $\begin{array}{l}\text { Must provide } \\
\text { direct access to } \\
\text { third parties }\end{array}$ & 1 & & \\
\hline T12 & $\begin{array}{l}\text { Requires } \\
\text { special user } \\
\text { training } \\
\text { facilities }\end{array}$ & 1 & & \\
\hline T13 & $\begin{array}{l}\text { Must allow } \\
\text { concurrent } \\
\text { user }\end{array}$ & 1 & & \\
\hline TOTA & & & & \\
\hline
\end{tabular}

$\mathrm{TCF}=(0.01 * \mathrm{TC}$ factor $)+0.6$

Calculate EF (EXPERIENCE FACTOR)

TABLE III

Experience Factors

\begin{tabular}{|c|l|c|c|c|}
\hline $\begin{array}{l}\text { Experience } \\
\text { factor }\end{array}$ & $\begin{array}{l}\text { Factor } \\
\text { Description }\end{array}$ & $\begin{array}{l}\text { Wight } \\
\text { Factor }\end{array}$ & $\begin{array}{l}\text { Project } \\
\text { Rating }\end{array}$ & $\begin{array}{l}\text { Sub } \\
\text { Total }\end{array}$ \\
\hline E1 & $\begin{array}{l}\text { Familiar with } \\
\text { FTP software } \\
\text { Process }\end{array}$ & 1 & & \\
\hline E2 & $\begin{array}{l}\text { Application } \\
\text { Experience }\end{array}$ & 0.5 & & \\
\hline E3 & $\begin{array}{l}\text { Paradigm } \\
\text { Experience }\end{array}$ & 1 & & \\
\hline E4 & $\begin{array}{l}\text { Lead analyst } \\
\text { capability }\end{array}$ & 0.5 & & \\
\hline E5 & Motivation & 0 & & \\
\hline
\end{tabular}

$\mathrm{EF}=(-0.03 * \mathrm{E}$ factor $)+1.4$

In the Use Case Point approach we have to predict no of Actor (Table-V), no of Use Cases (Table-VI), TCF (Table-VII) and EF (Table-VIII).Record of latest and successful project can help us in prediction of these values.

An early project estimate helps managers, developers, and testers plan for the resources a project requires. As the case studies indicate, the UCP method can produce an early estimate within 20 percent of the actual effort, and often, closer to the actual effort than experts and other estimation methodologies [13].

\section{USE OF HISTORICAL DATA IN MODEL}

As we know that in COCOMO we need to predict the KLOC and other 22 parameter which is called Efforts Adjustment Factors. In the Use Case Point approach we have to predict the 13 Technical Complexity Factor and 08 Experience Factor.

Historical data provide us guidelines to predict these parameters. Historical improve our prediction .The idea of recording and utilizing data from experience when estimating software development effort is not new [5]. One of the strengths of this approach is that estimates are based on actual experience [6]. The problem is the often very unique nature of software development projects, which makes it difficult to assess how similar a new project is to a previous one. Estimation by analogy is, or at least has been, widely utilized in the software industry [7].

We have taken some projects of a small software development company and estimate the efforts for these project using Use Case Point approach without taking reference of historical data. Again we have estimated the efforts for the same project using historical data and we have found that on an average we got average $10 \%$ of improvement. This improvement definitely decreases the MRE.

TABLE IX

Comparison of Results

\begin{tabular}{|c|l|l|}
\hline $\begin{array}{l}\text { Name of } \\
\text { Project }\end{array}$ & $\begin{array}{l}\text { Effort Estimated } \\
\text { by Use Case } \\
\text { Point (in Man- } \\
\text { Hours) }\end{array}$ & $\begin{array}{l}\text { Effort Estimated by } \\
\text { Use Case Point with } \\
\text { experience data (in } \\
\text { Man-Hours) }\end{array}$ \\
\hline A & 1042 & 1138 \\
\hline B & 917 & 1015 \\
\hline C & 822 & 910 \\
\hline
\end{tabular}

Fist time we had predict the values of parameters on the basis of our experience and project requirements. But in second time we use historical data to predict the value of parameters and we have got such change. 
During the study we have found that if we have incorrectly predict even a single parameter and make of difference of value one then we get difference of 4 UCP (On an average) on per 1000 UUCP. That mean we are losing 80 man hours (4 $\mathrm{UCP} * 20$ Man-hours/UCP) on a single value of TCF or EF.

As we know that we have $13 \mathrm{TCF}$ and $08 \mathrm{EF}$. So 21 times we need to predict the correct value .On a single miss prediction we will got a major difference.

We had work on a project has around 1000 UUCP and try to illustrate the above study.

TABLE X

Estimation Results for UUCP $=1000$

\begin{tabular}{|l|l|l|l|l|}
\hline$\sum$ TCF & TCF & $\sum$ EF & EF & UCP \\
\hline 52 & 1.12 & 32 & 0.44 & 493 \\
\hline 51 & 1.11 & 32 & 0.44 & 488 \\
\hline 50 & 1.10 & 32 & 0.44 & 484 \\
\hline
\end{tabular}

TABLE XI

Estimation Results for UUCP $=2000$

\begin{tabular}{|l|l|l|l|l|}
\hline$\sum$ TCF & TCF & $\sum$ EF & EF & UCP \\
\hline 52 & 1.12 & 32 & 0.44 & 985 \\
\hline 51 & 1.11 & 32 & 0.44 & 977 \\
\hline 50 & 1.10 & 32 & 0.44 & 968 \\
\hline
\end{tabular}

In the above study we have assume that we had miss predicted only one parameter by value one. We can lose more UCP if we incorrectly predict the many parameters with more value.

\section{CONCLUSION}

In the study we have seen that prediction is important in efforts estimation .Your estimation will be better if you can predict better. Historical data play vital role in prediction, it recommend us what we have to do. Use of model with historical data can produce good result that we have seen. This paper shows that not only the check list, analogy based estimation, or expert estimation can perform better, estimation model can also perform better but assistance of historical data is must.

Neither estimation strategy has been shown to be superior in all cases [11]. All the models could not predict the actual against either the calibration data or validation data to any level of accuracy or consistency. No model is best for all situations and environment. [12]

A lot of estimation models and methods are suggested by the researchers , but no one is best suitable for all projects and all software companies .A good monitoring policy is always required to make your estimation as a success .Every time we have to check the gap between actual and estimated and take the actions to bridge the gap.
Every model and method required a little bit of modification according to your local environment .so modify the method according to your requirement and use it, it will produce better results.

\section{REFERENCES}

[1] K. Moløkken-Østvold and M. Jørgensen, "AReview of Surveys on Software Effort Estimation," in 2003 ACMIEEE International Symposium on Empirical Software Engineering (ISESE 2003), Frascati Monte Porzio Catone (RM), ITALY, 2003,pp. 220-230.

[2] M. Jørgensen and S. Grimstad, "Overoptimism in Software Development Projects:"The winner's curse"," in IEEE CONIELECOMP, Puebla, Mexico, 2005, pp. 280285.

[3] Karner Gautav "Resource Estimation for objector project "Objective system SF AB 1993.

[4] M. Jørgensen, "Forecasting of Software Development Work Effort: Evidence on Expert Judgment and Formal Models," Accepted for International Journal of Forecasting, 2007

[5] E. A. Nelson and A. Force, Management Handbook for the Estimation of Computer Programming Costs: System Development Corp.; Distributed by Clearinghouse for Federal Scientific and Technical Information, 1967.

[6] F. Walkerden and R. Jefferey, "An empirical study of analogy-based software effort estimation," Empirical Software Engineering, vol. 4, pp. 135-158, 1999

[7] Kristian Marius Furulund1 and Kjetil Moløkken-Østvold "Increasing Software Effort Estimation Accuracy Using Experience Data, Estimation Models and Checklists " Seventh International Conference on Quality Software (QSIC 2007) pp 342-347

[8] Bohem," Software Engineering Economics", Prentice Hall, 1981.

[9] M. Jørgensen and D. I. K. Sjøbert, "Impact of experience on maintenance skills," Journal of Software Maintenance and Evolution: Research and Practise, vol. 14, pp. 123146, 2002.

[10] M. Jørgensen, "A Review of Studies on Expert Estimation of Software Development Effort," The Journal of Systems and Software, vol. 70, pp. 37-60, 2004.

[11] Saleem Basha, Dhavachelvan P "Analysis of Empirical Software Effort Estimation Models" (IJCSIS) International Journal of Computer Science and Information Security, Vol. 7, No. 3, 2010

[12] Carroll, Edward R. "Estimating Software Based on Use Case Points." 2005 Object-Oriented, Programming, Systems, Languages, and Applications (OOPSLA) Conference, San Diego, CA, 2005.

[13] ${ }^{1}$ Vahid Khatibi, ${ }^{2}$ Dayang N. A. Jawawi "Software Cost Estimation Methods: Review", Journal of Emerging Trends in Computing and Information Sciences Volume 2 No. 1 January 2011. 